\title{
New Caucasian species of soldier-beetles (Coleoptera: Cantharidae)
}

\section{Новые виды кавказских жкуков-мягкотелок (Coleoptera: Cantharidae)}

\author{
S.V. Kazantsev \\ C.B. Казанцев
}

Insect Centre, Donetskaya 13-326, Moscow 109651 Russia. A.N. Severtsov Institute of Ecology and Evolution, Russian Academy of Sciences, Leninskii Prosp. 33, Moscow119071 Russia. E-mail: kazantss@mail.ru.

Инсект-центр, ул. Донецкая 13-326, Москва 109651 Россия. Институт проблем экологии и эволюции им. А.Н. Северцова РАН, Ленинский просп. 33, Москва 119071 Россия.

Key words: Coleoptera, Cantharidae, new species, Palaearctic.

Ключевье слова: Coleoptera, Cantharidae, новые виды, Палеарктика.

\begin{abstract}
Three new species of soldier-beetles of the genera Rhagonycha Eschscholtz, 1830 and Malthodes Kiesenwetter, 1852, Rh. araratica sp.n., Rh. ritsaensis sp.n. and M. lozovoyi sp.n., are described from Armenia and Abkhasia.

Резюме. Из Армении и Абхазии описываются три новых вида жуков-мягкотелок из родов Rhagonycha Eschscholtz, 1830 и Malthodes Kiesenwetter, 1852, Rh. araratica sp.n., Rh. ritsaensis sp.n. и M. lozovoyi sp.n.
\end{abstract}

\section{Introduction}

An opportunity to study the Cantharidae material collected in the Caucasus recently allows adding new species to the genera Rhagonycha Eschscholtz, 1830 and Malthodes Kiesenwetter, 1852, which belong in the subfamilies Cantharinae and Malthininae, respectively. These two genera are among the most wide-spread and species-rich in the Palaearctic realm [Kazantsev, Brancucci, 2007]. While the Caucasian species of the first of the two genera, Rhagonycha, have not been reviewed yet, species of the second genus, Malthodes, were recently studied [Wittmer, 1992]. Two of the three new taxa described below were collected during the 2021 entomological expedition to Abkhasia: in Ritsa Relic National Park and at the Hodzhal Mountain area; the third species was collected in Khosrov Reserve in Armenia. The number of species registered in the region is thus increased from 34 in Rhagonycha and 23 in Malthodes [Kazantsev, 2012] to 35 and 24.

\section{Material and methods}

The studied specimens were glued on cardboard mounting plates. For detailed examination they were relaxed in water; then the detached ultimate abdominal segments were treated for several hours in $10 \% \mathrm{KOH}$ at room temperature for easier genitalia extraction, then the extracted genitalia were placed in microvials with glycerin for photographing.

MSP-1 zoom stereoscopic dissecting microscope with $\mathrm{x} 8-\mathrm{x} 80$ magnification range was used. Photographs were taken with Canon EOS 6D camera and Canon MPE $65 \mathrm{~mm}$ lens.

The following acronym is used in the paper: ICM Insect Center, Moscow.

\section{Taxonomy}

Cantharidae Imhoff, 1856 (1815)

CantharinaeImhoff, 1856(1815)

Cantharini Imhoff, 1856(1815)

Rhagonycha Eschscholtz, 1830

Rhagonycha Eschscholtz, 1830: 64

Type species: Cantharis fulva Scopoli, 1763

Distribution. Holarctic and Oriental regions.

Rhagonycha araratica Kazantsev, sp.n. Figs 1-2.

Material. Armenia: Holotype $-\sigma^{7}$, Ararat Distr., Khosrov reserve, 3.VI.1987, O. Lukashuk leg. (ICM).

Description. Male. Dark brown; head, except cheeks, black; pronotal sides, elytra, except at humeri, lateral margins and apices, and trochanters testaceous.

Vertex matt, finely and densely rugulose. Eyes small, interocular distance ca. 1.8 times greater than eye diameter. Clypeus short, rounded anteriorly. Palps slender; ultimate palpomeres elongate, weakly securiform, widest in distal half.

Pronotum transverse, ca. 1.2 times wider than long, almost parallel-sided, with weakly concave in anterior two thirds sides, almost straight basally and inconspicuously convex anteriorly. Scutellum relatively brad, gradually narrowing distally and rounded at apex. 


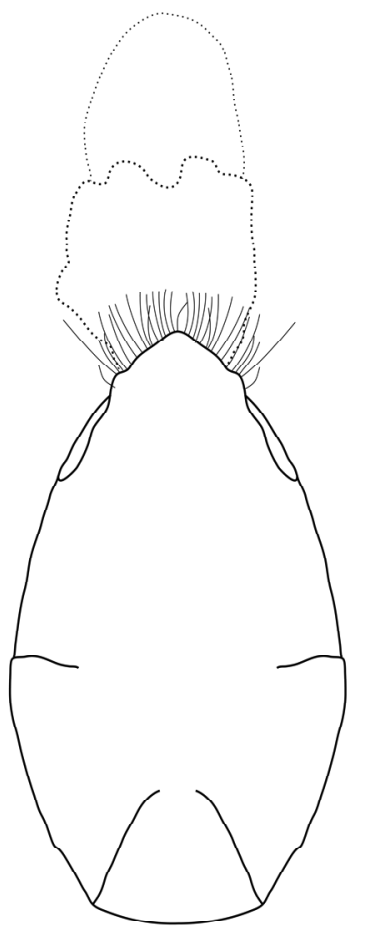

1

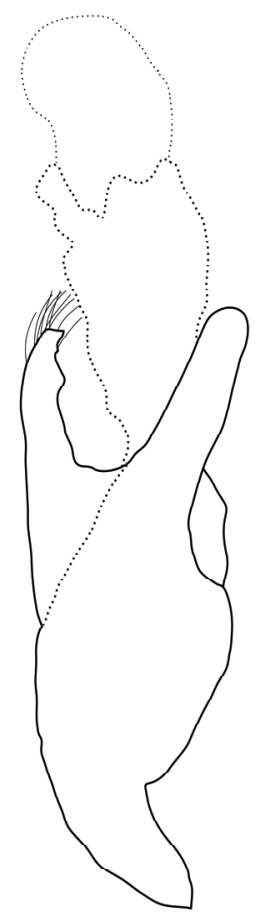

2

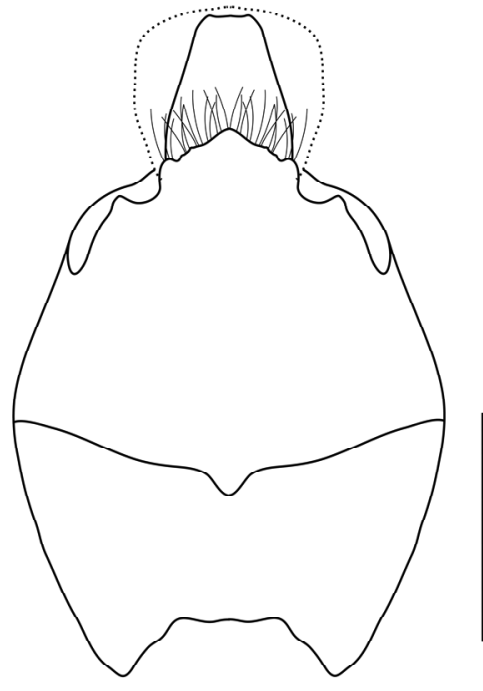

3

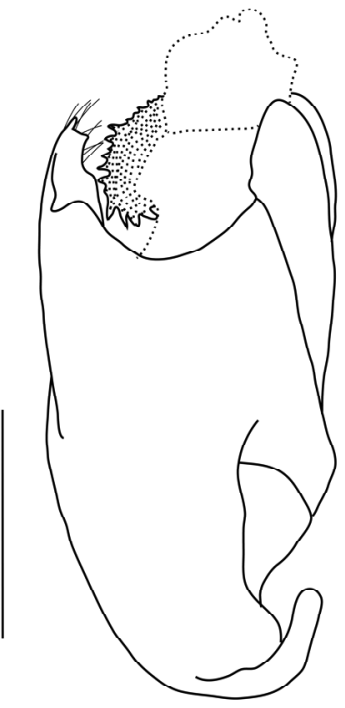

4
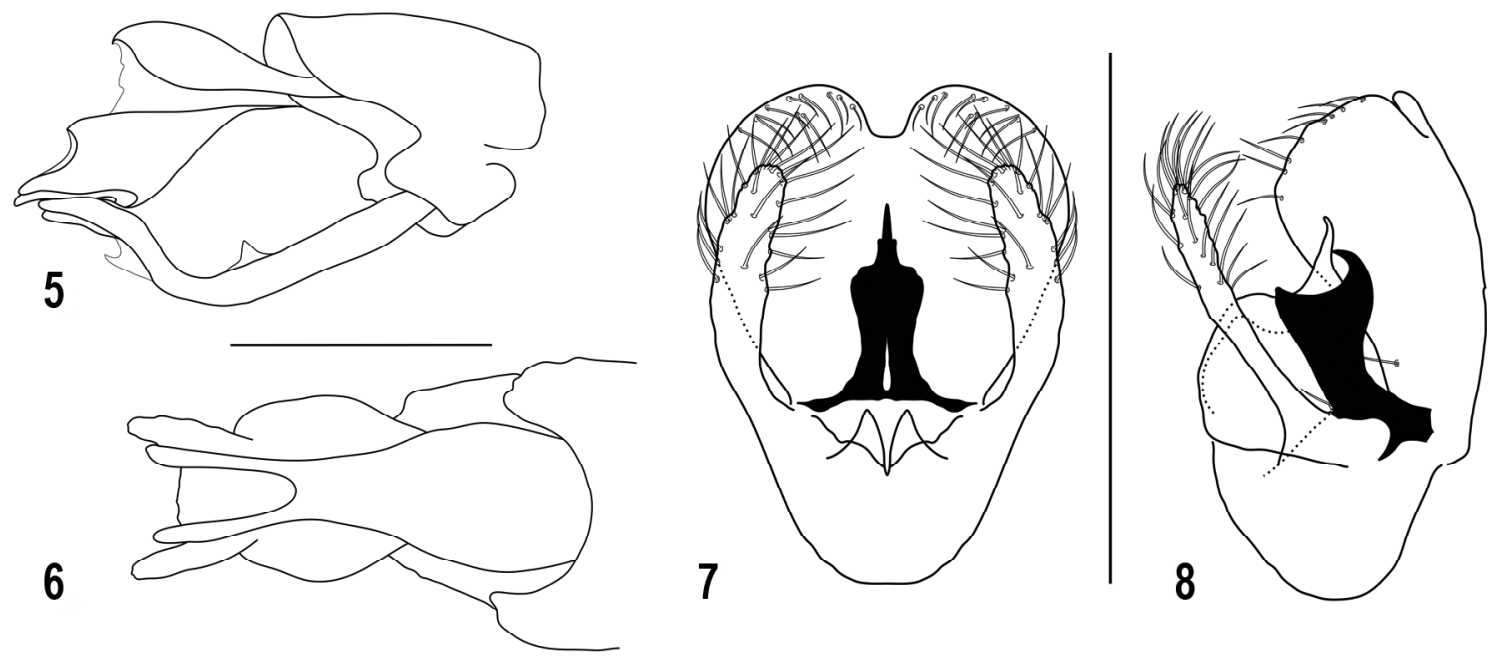

Figs 1-8. Abdominal terminalia and aedeagi of Rhagonycha and Malthodes, holotype males: 1-2 - Rh. araratica sp.n.; 3$4-$ Rh. ritsaensis sp.n.; 5-8 - M. lozovoyi sp.n.; 1-4, 7-8 - aedeagi; 5-6 - abdominal terminalia; 1, 3, 6 - ventrally; $7-$ dorsally; 2, 4, 5, 8 - laterally. Scale bar $0.5 \mathrm{~mm}$.

Pис. 1-8. Вооружение вершины брюшка и эдеагусы Rhagonycha и Malthodes, голотипы, самџы: 1-2 - Rh. araratica sp.n.; 3-4 - Rh. ritsaensis sp.n.; 5-8 - M. lozovoyi sp.n.; 1-4, 7-8 - эдеагусы; 5-6 - вооружение вершины брюшка; 1, 3, $6-$ снизу; 7 - сверху; 2, 4, 5, 8 - сбоку. Масштабная минейка 0,5 мм.

Elytra long, ca. 2.9 times longer than wide at humeri, slightly widening distally, with traces of oblique longitudinal costae, finely punctate proximally and tuberculate distally; pubescence short and sub-erect.

Legs long, slender; tibiae and femoris straight, narrow; hind tibiae noticeably longer than hind femoris.

Aedeagus elongate, with relatively slender straight parameres; dorsal plate with triangular elongate apex and trapezoidal pre-apical part (Figs 1-2).
Female. Unknown.

Length: $6.0 \mathrm{~mm}$. Width (humerally): $1.5 \mathrm{~mm}$.

Etymology. The new species is named after the locality where the holotype was collected.

Diagnosis. Rhagonycha araratica sp.n. resembles $R h$. holzschuhi Wittmer, 1972, known only from central Turkey, from which it can be distinguished by the smaller size, only $6 \mathrm{~mm}$ compared to $9.5 \mathrm{~mm}$ in $R h$. holzschuhi, as well as by the trapezoidal apex of the dorsal plate and straight parameres 
of the aedeagus (Figs 1-2), compared to parallel-sided apex and curved parameres in Rh. holzschuhi (Wittmer, 1972).

Remarks. Antennomeres 3-11 in the unique holotype are missing.

\section{Rhagonycha ritsaensis Kazantsev, sp.n. Figs 3-4.}

Material. Ablhasia: Holotype - $\sigma^{7}$, Ritsa Relic N.P., NNW Avadkhara Stn, subalpine (zone), $43.548^{\circ} \mathrm{N} 40.657^{\circ} \mathrm{E}$, 1800-2000 m a.s.l., 9.VII.2021, S. Kazantsev leg. (ICM); paratype $\sigma^{r}$, N Sukhum, Bzyb Mts, Chedym Mt., N slopes,

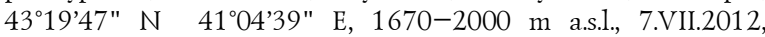
A. Prosvirov leg. (ICM).

Description. Male. Testaceous; head, except at clypeus, and antennae black; tarsi dark brown.

Vertex matt, finely and densely rugulose, with somewhat larger scarce tubercles. Eyes small, interocular distance ca. 2.3 times greater than eye diameter. Clypeus short, rounded anteriorly. Palps slender; ultimate palpomeres elongate, weakly securiform. Antennae long, filiform, attaining to elytral five sixths; antennomere 3 ca. 2.1 times longer than antennomere 2 and ca. 1.1 times shorter than antennomere 4; antennomeres 3-11 with scarce semi-erect pubescence.

Pronotum slightly transverse, ca. 1.1 times wider than long, semi-trapezoidal, with somewhat concave in anterior two thirds sides, almost straight basally and weakly convex anteriorly. Scutellum relatively narrow, narrowing distally and rounded at apex.

Elytra long, ca. 3.1 times longer than wide at humeri, widening distally, without longitudinal costae, finely punctate proximally and tuberculate distally; pubescence moderately dense and long, sub-erect.

Legs long, slender; tibiae and femoris straight, narrow; hind tibiae noticeably longer than hind femoris.

Aedeagus semi-oval, with robust parameres; dorsal plate with triangular transverse apex and trapezoidal pre-apical part; median lobe with spiny inner sac (Figs 3-4).

Female. Unknown.

Length: $8.0-8.4 \mathrm{~mm}$. Width (humerally): $1.9-2.0 \mathrm{~mm}$.

Etymology. The new species is named after the national park where the holotype was collected.

Diagnosis. Rhagonycha ritsaensis sp.n. appears to be close to Rh. nurdagensis Wittmer, 1972, from southeastern Turkey, separable by the trapezoidal apex of the dorsal plate of the aedeagus (Figs 3-4), compared to the parallel-sided apex in Rh. nurdagensis (Wittmer, 1972).

Variation. In the paratype the head is uniformly testaceous.

Malthininae Kiesenwetter, 1852

Malthodini Böving et Craighead, 1930

Malthodes Kiesenwetter, 1852

Malthodes Kiesenwetter, 1852: 242

Type species: Malthinus marginatus Latreille, 1806

Distribution. Holarctic, Oriental and Neotropical regions.

\section{Malthodes lozovoyi Kazantsev, sp.n.}

Figs 5-8.

Material. Abkhasia: Holotype - $\sigma^{\top}$, E Abkhasia, NE Akarmara, Hodzhal Mt. southern foothills, Fagus forest, $42.922^{\circ} \mathrm{N} 41.874^{\circ}$ E, 1300-1800 m a.s.l., 17.VII.2021, S. Kazantsev leg. (ICM); paratype + , idem (ICM).
Description. Male. Dark brown to black; clypeus, basal palpomeres, pronotal margins and knees brownish testaceous.

Vertex flat, finely punctate. Eyes moderately large, interocular distance ca. 1.2 times greater than eye diameter. Clypeus rounded. Palps slender; ultimate palpomeres relatively small, elongate, pointed apically. Antennae long, reaching over elytral apices, filiform; antennomere 3 ca. 1.25 times longer than antennomere 2 and ca. 1.2 times shorter than antennomere 4; antennomeres $2-11$ with relatively dense, short, semi-erect pubescence.

Pronotum slightly transverse, ca. 1.1 times wider than long, with noticeably concave sides, conspicuously convex basally and almost straight anteriorly. Scutellum transverse, slightly narrowing distally and rounded at apex.

Elytra moderately long, ca. 2.3 times longer than wide at humeri, parallel-sided, without traces of longitudinal costae, finely punctate proximally and roughly rugulose distally; pubescence short and decumbent.

Legs long, slender; tibiae and femoris straight, narrow; tibiae subequal in length to femoris.

Terminal tergite transverse, with a pair of elongate appendages, penultimate tergite unmodified sides, third from the apex tergite with a pair of short blunt teeth at base; terminal sternite elongate, constricted in the middle and abruptly bent in lateral view before apex, with a pair of straight elongate appendages distally and acute triangular tooth on inner side (Figs 5-6).

Aedeagus semi-oval, with rounded and medially notched distal margin of ventral plate and distinctly widened before apex, in dorsal view, laterophyses; parameres elongate and straight, noticeably shorter than ventral plate (Figs 7-8).

Female. Similar to male, but eyes smaller and antennae distinctly shorter.

Length (from anterior head margin to end of folded wings): $4.7-4.8 \mathrm{~mm}$. Width (humerally): $0.9-1.0 \mathrm{~mm}$.

Etymology. The species is named after Dr. Alexander Lozovoy (Moscow) who greatly contributed to the success of the 2021 Abkhasia expedition.

Diagnosis. Malthodes lozovoyi sp.n. is close to M. nyholmi Wittmer, 1970, distributed from northern Caucasus to Turkey, but is easily separable by the abruptly bent and conspicuously narrowed in the middle distal sternite, as well as by the rounded distal margin of the ventral plate of the aedeagus and distinctly widened in dorsal view laterophyses (Figs 5-8).

\section{Acknowledgements}

It is my pleasant duty to express gratitude to Dr. I.V. Tania (Ritsa Relic National Park) for her invaluable help during the field work in the Ritsa Relic National Park and to Dr. Alexander Lozovoy (Moscow) for his assistance with the Mt. Hodzhal part of the 2021 Abkhasia expedition.

\section{References}

Kazantsev S.V. 2012. An annotated checklist of Cantharoidea (Coleoptera) of Russia and adjacent territories // Russian Entomological Journal Vol.20 No.4. (2011). P.387-410. Kazantsev S.V., Brancucci M. 2007. Cantharidae // Löbl I., Smetana A. (Eds): Catalogue of Palaearctic Coleoptera. Vol.4. P. 234-298. Stenstrup: Apollo Books. 935 p. 
Wittmer W. 1972. 56. Beitrag zur Kenntnis der palaearktischen Cantharidae (Col.) // Mitteilungen der Schweizerischen Entomologischen Gesellschaft Vol.45. P.61-77.
Wittmer W. 1992: Die Malthininae (Coleoptera Cantharidae) des Caucasus // Russian Entomological Journal Vol.1. No.1. P. 17-35.

Поступила в редакцию 5.8 .2021 